\title{
Interlocking directorates and corporate networks
}

\author{
Forthcoming in Handbook of the International Political Economy of the Corporation, \\ edited by Andreas Nölke and Christian May
}

\begin{abstract}
J. P. Sapinski, University of Victoria, sapinski [at] uvic [dot] ca William K. Carroll, University of Victoria
\end{abstract}

\begin{abstract}
This chapter provides an introduction to the literature on interlocking directorates and corporate networks. It first traces the historical roots of the field back to the early 20th century, when researchers on both sides of the Atlantic started expressing concern about the threat to democratic process posed by the emergent corporate form, the potential for collusion allowed by the growing practice of interlocking directorate, and the general concentration of power in the hands of large firms and banks. It then outlines the major theoretical approaches employed, that focus on the corporate network as a set of both interorganizational and interindividual relationships. Third, it summarizes the main findings on the cohesiveness of the corporate community, the hegemonic position of banks, and historical changes and longitudinal dynamics of the network. Finally, it discusses most recent debates on the globalization, the emergence of a European corporate network, and the decline and recomposition of the corporate community.
\end{abstract}

Introduction: problem, methods and approaches

Power structure research and social network analysis

Early studies of interlocking directorates and corporate networks date from the formative era of corporate capitalism at the turn of the twentieth century, when many of the smaller firms of competitive capitalism were consolidated into the forerunners to today's giant corporations. These studies were motivated by a deep concern over the increasing potential for collusion which the corporate form brought about, which for some threatened competitive markets, but for others posed a direct threat to democratic institutions, as power was being hoarded for the benefit a minority. In the first important investigation, Otto Jeidel (1905) discovered 1350 interlocking directorates in Germany between the six biggest banks and industry. For him, the interlocks network marked "a new phase in German industrial development caused by concentration and launched by the economic crisis of 1900" (Fennema and Schijf 1978: 298). Jeidel's is precisely the diagnosis at the centre of Rudolf Hilferding's Finance Capital (1981 [1910]). In the same era, Louis D. Brandeis 
published his expose of American corporate capital. Based on findings from the congressional Pujo Committee investigation of the so-called "money trust", Brandeis showed how concentration of share ownership enables major investors, including financial institutions, to control “other people's money" (Brandeis and Hapgood 2009 [1914]), and pointed to the intricate elite networks that interlocking directorates had come to underwrite. Subsequently, an empirical literature on corporate elites would emerge around key studies such as Mills (1956), Porter (1956) and Domhoff (1967). With advances in the 1970s in computing capacity and the contemporaneous development of graph theory as a branch of applied mathematics attuned to networks, social scientists turned to network analysis as a means of representing elite and intercorporate relations. In a case of "multiple discovery", such developments emerged from similar concerns on both sides of the Atlantic (Fennema and Heemskerk 2016). Using social network analysis, scholars in both the United States and the Netherlands developed an evidence-based body of literature exposing the structure of corporate power that provided an alternative to pluralist accounts which had portrayed economic and political power as relatively dispersed and segregated into separate fields (Helmers et al. 1975). In a debate revolving around the unity and cohesiveness of the corporate elite, new methods of network analysis offered objective means of revealing and mapping elite cohesion and the capacity for political action (Domhoff 2016).

To take up the research literature on interlocking directorates and corporate networks, some terminology is needed. Any network is composed of points (or nodes) that represent the entities of interest, and lines (or edges) that show relationships between them. A key property of corporate-interlock networks is their duality (Breiger 1974; Carroll 1984): they are composed of both corporations and the persons who actually 'carry' the interlocks by virtue of their multiple corporate affiliations. Since they contain two kinds of nodes (directors and corporations), with lines running only between one kind and the other, they are termed 'two-mode' or 'affiliation' networks. When an individual sits on two corporate boards concurrently, (s)he is said to hold interlocking directorships with the two companies, which also means that the directorates of the companies interlock, tying them together at the level of governance. For individuals, interlocking directorships enable participation in the governance of multiple firms, enhancing contacts, influence and prestige; for firms, interlocking directorates put boards in contact, and may enable coordination of business strategies within an interlocked group (Mizruchi 1996). Conjoining these levels, multiple corporate affiliations simultaneously draw together key individuals and large corporations into extra-market forms of economic organization which are also forms of structuration of capitalist classes (Scott 1985: 2). 


\section{Theoretical Approaches}

Power structure research affirmed the value of embedding corporations in the wider system of power and influence that shapes corporate decisions and policies. The network approach traded the "aggregative" methods of classic elite analysis (which studied the attributes of units of analysis - individuals or corporations - but not their interrelations) for a structuralrelational approach foregrounding how the units comprising the system (whether individuals or corporations) are themselves shaped by their positions in networked configurations (Berkowitz 1980).

Still, there are multiple theoretical approaches in this field, which Scott (1985) has classified along two dimensions: an agent-system axis, and an organization-individuals axis. The intersection of these defines four approaches (see Table 1).

Table 1. Approaches to the study of interlocks

\begin{tabular}{lcc}
\hline & \multicolumn{1}{c}{ Agent } & System \\
\hline Individuals & Social background & Class cohesion \\
Corporations & Organizational & Intercorporate \\
\hline
\end{tabular}

Source: Scott (1985:3).

Continuing in the aggregative, pre-network mode of analysis, agent-centered approaches focus either on organizational agents, in which case interlocks are coded as a firm-level variable that can be statistically related to performance or profitability (Pfeffer 1987), or individual agents, in which case interlocks become properties of individuals, to be correlated with other personal characteristics, like wealth, education, class background and club membership (Domhoff 1967, 1974). Studies in the UK, for instance, have shown that most corporate directors share a similar social background of inherited wealth and privilege and that the elite's educational and social background became increasingly homogeneous in the 20th century (Stanworth and Giddens 1975). But in reducing corporate affiliations to mere attributes, information on the actual system of relations that constitute the elite is lost (Scott 1985: 4).

System-oriented approaches have built on the strengths of applied network analysis, within three theoretical perspectives. First, viewing corporations as formal organizations and corporate networks as intercorporate and interorganizational fields (Breiger 1974; Palmer 1987), some researchers introduced ideas from the study of formal organization, as in Pfeffer's (1987) view that interlocks help manage environmental uncertainty by securing access to necessary resources from other corporations (cf. Pennings 1980). However, issues of class, power, and capital accumulation have not been pursued by interorganizational researchers. 
A second inter-corporate perspective views interlocks as instrumental means in the accumulation and control of capital. Earlier research had taken up this perspective, based on Hilferding's conception of finance capital as an integration of the financial and industrial forms of capital, placing banks in central locations within a power structure segmented into "financial groups" of aligned firms (e.g., Menshikov 1969; Park and Park 1973). In their study of the power structure of American business in the 1960s, Mintz and Schwartz (1985) analyzed how, by controlling flows of capital, banks shape industrial structure, acting as "vehicles for the class control of the economy" (1985: 254). Their central position in the interlock network was seen to reflect their hegemonic role as mediators of intra-class competition and meeting points for finance capitalists. For Mintz and Schwartz, financial hegemony operates in part through corporate affiliations, both at the level of system and agent. At the organizational level, bank-centered interlocks provide a broad scan across sectors of the business community; at the individual level the same interlocks help forming an elite of finance capitalists, "a cohesive group of multiple directors tied together by shared background, friendship networks and economic interests, who sit on bank boards as representatives of capital in general" (1985: 254).

The third, class hegemony perspective sees corporations as "units in a class controlled apparatus of appropriation" (Soref and Zeitlin 1987: 58). In this system-oriented view, the wider context for corporate decision making it a network not of organizations, but of individuals within the dominant class, whose particular interests are crystallized not in specific corporations but in control groups (families, kinecon groups or financial cliques), and whose general class interests are strengthened by the many weak ties of interlocking outside directors. Interlocks are considered an expression of class cohesion, integrating potentially contradictory interests (financial, industrial, commercial) of the richest families, whose investments span across sectors (Soref and Zeitlin 1987: 60). In the class hegemony perspective interlocks serve as communication channels between individual directors, facilitating a common worldview among them (Koenig and Gogel 1981), and offering the "inner circle" access to a broad resource base from which to exert their hegemony in and beyond business circles (Useem 1984).

System-centred approaches have enriched our understanding of interlocking directorates by highlighting the embedded character of corporations and directors and depicting the power structure as a formation within which elite individuals and capitalist enterprises pursue particular goals while often contributing to wider class-based interests, as in the solidification of class hegemony and the allocation of investment capital. Various authors have emphasized the complementarity between these approaches (Koenig and Gogel 1981; Scott 1985; Stokman et al. 1988). Together, they treat corporate interlocks as "traces of power" (Helmers et al. 1975) of two kinds: instrumental power associated with capital 
accumulation and expressive power associated with class hegemony (Carroll 2004; Sonquist and Koenig 1975).

In this regard, Scott's observation that "power in intercorporate networks is based on at least three distinct kinds of intercorporate relations: personal, capital and commercial" has value. Capital relations "are the links between business agents that result from shareholdings and from the granting and withholding of credit" (Scott 1991: 184). Of particular significance in decoding interlocks as traces of instrumental power is the tendency, highlighted in the concept of finance capital, for capital relations to undergird interlocking directorships, including family control of multiple firms, institutional shareholding, intercorporate ownership, and the credit relations through which banks exercise allocative power vis-à-vis debtors (Scott 2003: 159).

\section{Main findings}

After the methodological and theoretical developments of the 1970s and early 1980s, power structure research experienced a decline as several of the key scholars moved to organizational studies and business schools (Fennema and Heemskerk 2016). Starting in the early 2000s, globalized capitalism provided a new impetus for the study of interlocking directorates. We will first summarize the major findings of the field, that can be traced back to the early period, before discussing the later debates revisiting some of these conclusions.

\section{A cohesive elite}

Studies of interlocking directorates and corporate networks in the closing decades of the twentieth century consistently revealed how corporate directors form an elite. An elite refers to "those who occupy the most powerful positions in structures of domination" (Scott 2008: 33 ), and a cohesive elite forms an "organized minority" that may function as the "leading edge" of a ruling class (Brownlee 2005). Research on interlocking directorates and corporate networks has consistently shown high levels of elite integration - in effect, a "small world" comprised of leading corporations and their directors (Kogut 2012). In these networks, there is almost always an elite within the elite: the networkers, and particularly the "big linkers" (each holding four or more major corporate affiliations). These comprise a small fraction of all corporate directors and executives but typically carry the lion's share of all interlocking directorships. In a key investigation, Useem (1984) concluded that elite corporate networkers constitute the "dominant segment" of the capitalist class, an "inner circle" possessing greater wealth than single-firm directors, with more connections to financial institutions and a higher degree of social cohesion and of political influence (Useem 1984). Useem's research and similar studies showed that the reach of corporate networks extends beyond the world of capital - through the many venues where directors 
meet, exchange ideas, and discuss economic and political issues. The participation of networked directors not only on corporate boards but on the boards of civic and political organizations (foundations, university boards of governors, social clubs, business associations, think tanks and forums) fosters social cohesion (Barnes 2017). Concomitantly, the corporate-interlock network, layered upon personal networks that reach back to common social and educational backgrounds, promotes a common worldview (Koenig and Gogel 1981) and an ongoing basis for elite consensus and concerted political agency (Domhoff 2014).

Thus, complementing corporate interlocking are other forms of elite integration, in particular the interlocking directorates of key policy-planning think tanks, institutes and forums. Here the structural implication of an organized minority are clear: the hierarchical character of the corporate elite is amplified by the tendency to pull the well-connected corporate directors onto the boards of the policy-planning groups, further shrinking the social space of the elite while connecting business leaders to intellectuals and leaders from other fields in dialogues that foster a unified voice. Heavily populated with corporate directors, the governance boards of such elite policy-planning groups as the World Economic Forum and the World Business Council for Sustainable Development are themselves densely interlocked (Carroll and Carson 2003; Carroll and Sapinski 2010). A comparison of the leading transnational business councils with leading transnational alternative policy groups advocating global justice (such as the Transnational Institute and Focus on the Global South) found in the former case that $72 \%$ of all pairs of boards shared directors while in the latter case only five percent were interlocked. The stark difference in the extent of interlocking reflected not only massive resource disparities but also the difference between a hierarchically organized minority and a largely disorganized majority whose structures are more horizontal. The former is inherently easier to pull together via ties among the relative few at the top (Carroll 2013).

Elite schools and universities also play a key role in the cohesiveness of the corporate elite and its reproduction. Like policy groups and economic forums, their boards provide spaces for individuals to meet and a means to extend their power within the institutions of civil society (Slaughter et al. 2014). Even more so, they are the main institutions participating in the production and reproduction of the elite, as they socialize aspiring elite members and later sanction their belonging to the group through the granting of degrees that act as symbols of the social capital possessed by elite members (Bourdieu 1996; Stanworth and Giddens 1975). 


\section{Bank hegemony}

A second key finding from the research literature of the late twentieth century concerned the central position that banks hold within corporate networks. In their comprehensive review at the end of the 1970s, Fennema and Schijf observed that in all advanced capitalist societies "financial institutions, banks and insurance companies have central positions in the network of interlocking directorates" (1978: 327). Recalling Scott's (2003: 159) thesis that interlocking directorates must be viewed "alongside the capital relations that undergird them", certain key studies pointed to the symbiosis between financial capital and industrial capital as the basis for the centrality of banks in corporate networks. Ratcliff's (1980) study of 78 St. Louis banks evidenced a strong relationship between a bank's centrality in the interlock network and its loans to capitalists. This suggested that the personal union of banking and corporate interests at the centre of the capitalist class "is associated with a major flow of loan capital from banks to corporations and other related borrowers" (Ratcliff 1980: 565) - an interpretation consistent with Mintz and Schwartz's concept of "financial hegemony" (1985).

Although firm-by-firm data on bank loans is not generally available, data on intercorporate ownership has been widely employed in studies of corporate networks. Windolf's (2002) comparative investigations of American and European corporate networks included ownership ties, and revealed sharp differences between continental regimes such as Germany's, where ownership and interlocking often coincide, and Anglo-American networks which show few instances of significant intercorporate ownership and little overlap between the networks. Kogut and Walker (2001: 325) tracked 101 acquisitions between 1993 and 1997 involving 550 German corporations. They reported tendencies for acquisitions to make the network more centralized and for leading financial institutions to act as "brokering owners" in mergers and acquisitions. Grbic (2007) mapped the Japanese bank ownership network from 1988 to 1999 and found a dense network of institutional investors whose core actors were almost entirely financial institutions. These studies show how, in some measure, national corporate networks are underpinned by capital relations entailing combinations of what Scott (1997) terms allocative power over financial flows and strategic control of firms through share ownership.

\section{Temporal dynamics}

Complementing the issue of spatial distribution, studies from the 1970s onward tracked the temporal dynamics of corporate networks. Stanworth and Giddens (1975), in their study of the British network at seven points between 1906 and 1970, found the concentration of firms had increased, along with the number of ties among firms, while the largest firms drew closer to the City banks. Barnes' (2017) mapping of the interpersonal network of American 
corporate directors at four points from 1962 to 1995 documented the decline of cultural ties (eg, to museum and symphony boards) but a steady increase in elite affiliations with policy planning organizations - a shift from cultural leadership to political mobilization (cf. Carroll 2004; Useem 1984). A stronger longitudinal design uses a panel of firms to trace changes in both the composition of the set of largest corporations and the structure of relations among them. A study of the Canadian network during the post-war boom years (1946-76) used this approach to show that major structural transformations occurred around a 'stable core' of large banks and industrial corporations, as differential rates of accumulation and corporate reorganizations led other firms to enter or exit elite status, and as interlocks emerged or disappeared with corporate realignments (Carroll 1986).

Studies of broken and reconstituted interlocking directorates also use a panel design, but employ the intercorporate tie as the unit of analysis. Ornstein (1984) found that 30 percent of interlocks among large corporations in Canada that have been broken at some point during the first three post-war decades were restored again, but that the rate of restoration varied. Interlocks carried by executives in one of the linked firms, and interlocks that were part of a relation of intercorporate ownership or a multiple-director relation, were substantially more likely to be restored. Richardson (1987) used cross-lagged correlations to show that in Canada profitability of industrial firms in 1963 predicted the restoration of their interlocks with financial institutions five years later, in a "circular and self-sustaining process" that reinforced companies' original profit position, supporting the theory of finance capital as capital integration.

\section{Recent debates}

Studies since the turn of the century brought new light to bear on the classic themes laid out above. New legislation enacted in the 1990s in the face of recurrent economic crises and the reorganization of corporate activity led to changes in corporate governance. Efficiency was emphasized, board sizes were reduced accordingly and limits were placed in some countries on the number of concurrent boards executives could sit on. In parallel, corporations sought to increase board diversity and thus invited a greater number of women and members of minority groups (Heemskerk and Fennema 2014; Zweigenhaft and Domhoff 2013). In parallel, accumulation processes and corporate ownership were becoming increasingly transnational as the neoliberal regime was consolidated around the turn of the century, fostering some degree of internationalization of corporate boards. These developments inspired theoretical debates around the possible emergence and political capacity of a transnational capitalist class. Following from these political and economic changes, the findings from the earlier period were recast in the light of these regulatory changes and of broader debates around the organization of neoliberal capitalism. 
Decline vs. recomposition of the corporate elite

In his initial framing of the issue, Scott (1997) suggested that, with economic globalization corporate networks may follow in the tracks of national economies - becoming disarticulated as economic relations are rearticulated more globally. Using longitudinal designs, a number of studies have indeed reported a weakening of national corporate networks since the early 1990s, in the US (Chu and Davis 2016; Davis and Mizruchi 1999; Mizruchi 2013) and elsewhere (Carroll 2002; David and Westerhuis 2014; Heemskerk 2007). However, the reasons for this are complex. They have partly to do partly with corporate governance reforms that have tended to limit the size of directorates and the number of directorships each director holds (Carroll 2010: 93). Another factor has been the shift since the 1990s in finance from "patient money" to "agile money": from bank-centred relationship-based financing to transaction-based financing involving asset managers, hedge funds and private equity, "whose relations with big industry are more ephemeral and do not necessarily entail interlocking directorates" (Carroll 2010: 228).

As a consequence, bank boards declined in importance as sites for elite cohesion, which Davis and Mizruchi (1999) interpret as a transition from a system of bank control to one of market regulation of the economy. Mizruchi (2013) concludes from these observations that interlocking directorates can no longer function as a foundation for political unity among the corporate elite, resulting in the existing class-wide rationality being replaced by isolated corporations pursuing their narrow self-interests. Thus, according to this thesis, under neoliberal market regulation, national interlocks networks become disorganized as banks lose their function as organizing nodes in the economic system. This argument directly challenges the main conclusion of power structure research as a field of study, that is, that the cohesiveness of the corporate elite allows it to weigh in the political arena and determine in large part the terms of the debate (e.g., Domhoff 2014).

Nonetheless, recent scholarship offers alternative accounts of the implications of the observed decrease in density of national networks. Kogut (2012) report a persistence of the "small world" structure exhibited by many national networks, which forms the basis for intercorporate coordination - implying enduring cohesion of the corporate elite on some level even if the average density of ties has dropped (Kogut 2012: 29). Additionally, Heemskerk et al. (2016) find that in parallel to the decline of national interlocks networks, the transnational network of interlocks has been consolidating over the last four decades, especially within the European Union. For his part, Murray (2016) analyzes in detail the role of the transnational network in the cohesion of the corporate elite, both internationally and in the US. Disputing the fragmentation thesis, he first shows that despite the observed decline in network connectivity, US corporations still act politically in a unified way. Second, he finds that non-financial transnational corporate boards have in large part taken 
up the role of forging political cohesion once played by national bank boards. This finding thus recasts the apparent decline of the US national network as a process of reorganization ensuing from the globalizing circuits of capital (see also Carroll 2010).

Also contradicting the fragmentation thesis is the well-established role of a variety of venues in fostering corporate elite cohesion, as indeed interlocks networks are one part of a set of multiplex relationships linking members of the corporate community together (Barnes 2017). Early on, Domhoff (1967) showed that corporate elite members also meet in the context of think tanks and policy-planning groups, university boards, philanthropic foundations, among others. Burris (2008) and Carroll and Shaw (2001) show that think tanks such as the Business Roundtable in the US and the Fraser Institute in Canada were crucial in fostering business cohesion around the rightward shift and the consolidation of neoliberalism in the early 1980s. In Europe, the European Table of Industrialists has been since its inception a major site of transnational corporate elite mobilization in relation to the project of European integration (van Apeldoorn 2002). Global level organizations like the World Economic Forum and the International Chamber of Commerce play the same cohesive role to strengthen relations between transnational capitalists, and significantly reduce the spread of the transnational network of interlocks (Carroll and Sapinski 2010; Carroll and Carson 2003; Carroll and Sapinski 2016). Hence, evidence spanning several decades suggests a reorganization of corporate networks around different centres of coordination has been taking place, but it appears premature to claim that capitalists have become disorganized and thus lost their dominant political position.

\section{Varieties of corporate networks}

In recent decades, research on interlocking directorates and corporate networks has taken a comparative turn. An initial comparative-historical perspective on corporate networks was offered by John Scott (1985) and later revised to take account of the "post-Communist pattern" of collusive business organization in Eastern Europe and the "Chinese pattern" of corporate cooperation based in fraternal inheritance (Scott 1997, 2012). Scott emphasized the distinct routes that advanced capitalist countries had taken to the corporate regimes of the late 20th century, and the implications for network organization. Also in 1985, an international research group comparing intercorporate networks in 10 countries published its findings (Stokman et al. 1985).

These works showed how distinct patterns of economic development and corporate law had produced variant configurations of economic power within national business systems (cf. Whitley 1999). The German system of "oligarchic bank hegemony", in which banks were dominant in both capital allocation and control, is similar to the post-war Japanese system, where strategic and allocative power were also combined in bank-centred enterprise groups 
whose members held blocs of shares in each other. In France, Belgium and Italy, a "Latin model", organized around the wide-ranging shareholdings of rival holding companies, imparted "a granular, group structuring of the economy" and the network (Scott 1986: 136). An Anglo-American system of "polyarchic financial hegemony" took shape in the aftermath of the Great Depression, as large financial institutions held powerful allocative positions visà-vis industrial companies while institutional investors held shares that enabled them to function collectively as "constellations of interests", exercising a constraining strategic power upon corporate management. The "polyarchic" character of the Anglo-American system made for an interlock network centralized around financial institutions, with little to no fractioning into discrete financial groups (Scott 1986: 129-260).

In the early 21 st century further advances in data availability (in particular the development of giant corporate databases like Orbis) fuelled "a renaissance in director interlock research" (Cronin 2011: 44), extending the geographical scope as well as the scale of research and combining study of larger numbers of companies and directors with longitudinal analysis, often based on panel data. Edited collections of multi-country corporate network analyses investigated whether national and international corporate networks are clustered into tightly-knit "small worlds" (Kogut 2012), the changing structure of national networks over the 20th Century (David and Westerhuis 2014), and the question of "who rules the world" (Murray and Scott 2012).

Historical studies compare the institutional coordination mechanisms found in different national economies since 1900. David and Westerhuis (2016) identify four broad periods reflecting different economic coordination mechanisms: corporate networks rose between 1890 to 1930, during a period of global liberalism and laissez faire; national patterns then diverged following the emergence of communism; a period of very slow growth followed the Second World War as state interventionism grew; finally, national corporate networks declined after 1980, during the neoliberal period. Thus, the move from the welfare state to the neoliberal regime saw different interlocks patterns emerge, as the US and other AngloSaxon networks became increasingly decentralized, whereas networks in continental European countries retained greater cohesion as states held on to greater economic coordination. At the same time, the networks in post-Communist and semi-peripheral countries reorganized around business and family groups, that determined capital flows through ownership relations as well as informal and political networks (e.g., Lluch et al. 2014; Stark and Vedres 2012). In the same vein, Cárdenas (2012) reports that cohesive networks are generally found in countries with bank-based economies, strong state involvement and where firms are generally owned by few shareholders with large blocs of shares. In contrast, countries with market-based finance, non-interventionist states and dispersed shareholdings tend to have less cohesive networks. In a later study, he finds that 
the financial structure - bank- or market-based source of capital - cannot in the case of Latin America account for the variation observed among networks, instead explained by the presence and strength of business associations, the degree of market internationalization (Cárdenas 2016), as well as the business group structure of the economy (Lluch et al. 2014; Salvaj and Couyoumdjian 2016).

Hence, overall, the comparative approach delineates national and temporal variations in the ways capital is mobilized in support of capitalist firms - through the stock market, bank finance, the state, groups of firms, or the interpersonal networks of capitalists - and thus emphasizes the fundamental embeddedness of economic processes in social institutions and relations. In this way, its findings recast the fragmentation of the corporate elite thesis by showing that the observed decline in elite cohesion in the US and elsewhere reflect a reorganization alongside changing institutional arrangements rather than a mere decline of bank power (see David and Westerhuis 2014; Murray 2016). It also opens up to a consideration of how these national level mechanisms interact with global level dynamics. Sketching out such an analysis, Scott explains that the globalization of firm ownership ties all national economies together in a single transnational shareholder market in which pension funds, banks and holding companies from the core economies are major participants. "As a result, an increasing number of enterprises have found themselves subject to the substantial influence, if not control, of shareholding interests that are international in character" (Scott 2012: 20). The emergence of a transnational interlocks network has been much discussed, and it is to this question we now turn.

\section{The globalization of corporate networks}

Research on the global corporate network has been complementing the growing comparative literature. Key issues here have been (1) whether transnational interlocks are on the rise while national interlocks contained within countries are declining and (2) the geography of transnational interlocking and the question of regional networks. Fennema's (1982) pathbreaking study documented the consolidation of a Euro-North American interlock network in the 1970s, but found very few ties extending beyond that heartland of post-war capitalism. A more extensive analysis showed profuse interlocking across parts of continental Europe (particularly Germany/Netherlands and Belgium/France) but only sparse ties between the USA and continental Europe, with firms based in Britain accounting for most of the transatlantic traffic (Fennema and Schijf 1985). A replication of Fennema's original study comparing the network of 1976 with 1996 found only a modest increase in transnational interlocking alongside the persistence of national networks (Carroll and Fennema 2002). Kentor and Jang (2004) purported to show a more dramatic increase in 
transnational interlocking between 1983 and 1998; however, Carroll and Fennema (2004) questioned the validity of their data.

More recent research on the 500 leading corporations in the world has found a proliferation of transnational interlockers between 1996 and 2006 and a decline in national networkers, particularly in Japan, whose complement of leading corporations plummeted during the 1990s. With profuse ties to each other as well as to various national networks, transnationalists intermingle extensively in the global corporate elite's inner circle with national networkers; hence "whatever common interest takes shape is likely to blend 'national' and 'transnational' concerns" (Carroll 2009: 24). Indeed, Murray (2014) finds that the more central firms in the transnational interlocks network are more likely to contribute to US political campaigns, which he regards as evidence for the emergence of political cohesion among the leading edge of the global corporate community. As capital globalizes, a system of greater complexity emerges in which transnational interests do not replace but rather layer upon national dynamics, and where transnational corporations have come to play a specific role as they insert themselves into rearticulated national networks (Klassen and Carroll 2011; Murray 2016).

However, the increase in transnational interlocking has occurred largely within Europe (Carroll et al. 2010; Heemskerk 2011, 2013) and to some extent across the north Atlantic, "replicating the longstanding structure of imperialism" and forming "a kind of superstructure bridging national corporate communities", but not supplanting them (Carroll 2010: 224-25). Burris and Staples reached similar conclusions in their longitudinal analysis of the global network, and pointed to "the historic tie between the US and British capitalist classes as an essential bridge upon which the formation of a broader North Atlantic capitalist class crucially depends" (2012: 336). Prospectively, the UK's intermediary role in the transatlantic interlock network could weaken in the wake of a "Brexit" from the European Union (with corporate-elite ties between the UK and US strengthening), possibly weakening the unity of what van der Pijl (1984) termed an Atlantic ruling class. On the continent, international competition determines the making of the European corporate community, as France and Germany struggle for regional economic dominance (van der Pijl et al. 2011). In this process, some bi-lateral linkages find themselves strengthened (e.g., between France and Belgium), whereas on the contrary other countries like e.g. Italy become increasingly disconnected (Vion et al. 2015).

As corporate networks became reorganized along the requirements of global capital accumulation, a "new system of finance capitalism" (Davis 2008) emerged, in which ownership is concentrated among a few asset managers whose power resides more in their exit option than in direct participation on corporate boards. In a study of global corporate 
ownership based on 2009 data, Peetz and Murray (2012) reported that the top 30 institutional owners (21 of them financial institutions and nine of them states) hold or control 51.4 per cent of the total assets of the world's 299 leading corporations. Similarly, a 2011 study of the global corporate-ownership network estimated that a "super-entity" of 147 tightly knit companies (most of them financial institutions) controls 40 per cent of the total wealth in the global network of 43,060 corporations (Vitali et al. 2011: 6). Compared to the modest accretion of elite connections across borders and the attenuated persistence of national corporate-interlock networks, it is collective ownership structures among the world's largest corporations that have shown a dramatic degree of transnationalization in the early 21 st century.

Methodological advances allowed by greater computing power and "big data" analysis techniques confirm as well as add nuance to earlier findings about the structure of the transnational interlocks network. Using state-of-the-art community detection algorithms, Heemskerk and Takes (2016) find that the network of the one million largest firms in the world is mainly organized in regional clusters in which the North Atlantic axis is densely interlocked, and that a distinct Asian cluster has emerged. They outline a "multilevel structure where, in between the national and the transnational, discernible regional clusters play a fundamental role in the network architecture" (p. 112). A further study by the same research group expands the dataset to over five million corporations (Heemskerk et al. 2016). It confirms that interlocking patterns are organized along multiple levels in a nested structure. National boundaries still do play a major role in this structure, although many clusters form on a regional level, such as in Southwestern and Central Europe, whereas some reflect old colonial relations, and others reach across the Atlantic as in the case of Brazil and Portugal or the US and the UK. In all, the multi-level structure uncovered might provide a broad framework to bridge between the various patterns delineated by comparative studies and global level studies looking for signs of an emergent transnational corporate community.

\section{Conclusion}

Corporate elite studies have come a long way since the early studies of firm and bank interlocking concerned with collusion and financial hegemony, thanks to developments in social network theory and computing capacity. Today, the cohesiveness of corporate elites and their power to weigh on the political agenda is unquestioned. After a long period of bank hegemony, these firms have been replaced as a point of cohesion by transnational corporations and specifically political corporate organizations. Comparative and longitudinal studies have uncovered patterns of interlocking that vary according to country and time period. Finally, studies of transnational interlocking have given rise to debates 
about the rise of a cohesive and politically organized global corporate elite, within an uneven process in which national-level networks still account for the vast majority of links. Together, these studies telegraph a deep concern about democracy. Historically, scholarly activity on corporate power structures has intensified in periods of reorganization of capitalist accumulation following from economic crises. The early 20 th century saw the emergence of large corporations merging financial and industrial capital. Then, capitalist globalization took a new turn with the crisis of the Fordist regime in the 1970s. The more recent period is marked by the dual crisis of the economy and the environment. With each of these crises emerged concerns with the way economic relationships are organized, and the individuals and entities who have the power to decide how they should and will be rearranged. With each successive reorganization, power appears to become concentrated in ever fewer hands, and further removed from democratic control. Studies of interlocking directorates in the power structure research tradition have contributed to uncovering some of the workings of corporate elite power. 


\section{References}

Alderson, Arthur S. and Jason Beckfield. 2004. "Power and Position in the World City System." American Journal of Sociology 109(4):811-51.

Alderson, Arthur S. and Jason Beckfield. 2006. "Globalization and the World City System: Preliminary Results from a Longitudinal Data Set." Pp. 21-35 in Cities in Globalization: Practices, Policies and Theories, edited by Peter Taylor, Ben Derudder, Pieter Saey, and Frank Witlox. London: Routledge.

Barnes, Roy C. 2017. "Structural Redundancy and Multiplicity within Networks of US Corporate Directors.” Critical Sociology 43(1):37-57.

Berkowitz, S. D. 1980. "Structural and Non-Structural Models of Elites: A Critique." Canadian Journal of Sociology 5(1):13-30.

Blondel, Vincent D., Jean-Loup Guillaume, Renaud Lambiotte, and Étienne Lefebvre. 2008. "Fast Unfolding of Communities in Large Networks." Journal of Statistical Mechanics: Theory and Experiment 2008(10):P10008.

Borgatti, Stephen P. and Daniel Elgin. 2011. "Analyzing Affiliation Networks." in The SAGE Handbook of Social Network Analysis, edited by John Scott and Peter J. Carrington. London: SAGE Publications.

Bourdieu, Pierre. 1996. State Nobility: Elite Schools in the Field of Power. Stanford: Stanford University Press.

Brandeis, Louis D. and Norman Hapgood. 2009. Other People's Money and How the Bankers Use It. New York: Cosimo.

Breiger, Ronald L. 1974. “The Duality of Persons and Groups.” Social Forces 53(2):181-90.

Brownlee, Jamie. 2005. Ruling Canada: Corporate Cohesion and Democracy. Halifax: Fernwood Publishing.

Burris, Val. 2008. “The Interlock Structure of the Policy-Planning Network and the Right Turn in U.S. State Policy." Research in Political Sociology 17:3-42.

Burris, Val and Clifford L. Staples. 2012. "In Search of a Transnational Capitalist Class: Alternative Methods for Comparing Director Interlocks within and between Nations and Regions." International Journal of Comparative Sociology 53(4):323-42.

Cárdenas, Julián. 2012. "Varieties of Corporate Networks: Network Analysis and fsQCA." International Journal of Comparative Sociology 53(4):298-322. 
Cárdenas, Julián. 2016. "Why Do Corporate Elites Form Cohesive Networks in Some Countries, and Do Not in Others? Cross-National Analysis of Corporate Elite Networks in Latin America." International Sociology 31(3):341-63.

Carroll, William K. 1984. "The Individual, Class, and Corporate Power in Canada.” Canadian Journal of Sociology 9(3):245-68.

Carroll, William K. 1986. Corporate Power and Canadian Capitalism. Vancouver: University of British Columbia Press.

Carroll, William K. 2002. “Does Disorganized Capitalism Disorganize Corporate Networks?" Canadian Journal of Sociology 27(3):339-71.

Carroll, William K. 2004. Corporate Power in a Globalizing World: A Study in Elite Social Organization. Don Mills (ON): Oxford University Press.

Carroll, William K. 2007. "Global Cities in the Global Corporate Network." Environment and Planning A 39(10):2297-2323.

Carroll, William K. 2009. “Tracking the Transnational Capitalist Class: The View from on High.” Pp. 43-64 in Hegemonic Transitions: The State and Crisis in Neoliberal Capitalism, edited by Yildiz Atasoy. London: Routledge.

Carroll, William K. 2010. The Making of a Transnational Capitalist Class: Corporate Power in the 21st Century. London and New York: Zed Books.

Carroll, William K. 2013. "Networks of Cognitive Praxis: Transnational Class Formation from Below?” Globalizations 10(5):691-710.

Carroll, William K. and Colin Carson. 2003. "Forging a New Hegemony? The Role of Transnational Policy Groups in the Network and Discourse of Global Corporate Governance." Journal of World-Systems Research 9(1):67-102.

Carroll, William K. and Meindert Fennema. 2002. "Is There a Transnational Business Community?” International Sociology 17(3):393-419.

Carroll, William K. and Meindert Fennema. 2004. "Problems in the Study of the Transnational Business Community: A Reply to Kentor and Jang." International Sociology 19(3):369-78.

Carroll, William K., Meindert Fennema, and Eelke M. Heemskerk. 2010. “Constituting Corporate Europe: A Study of Elite Social Organization.” Antipode 42(4):811-43.

Carroll, William K. and Jean Philippe Sapinski. 2010. "The Global Corporate Elite and the Transnational Policy-Planning Network, 1996-2006: A Structural Analysis.” International Sociology 25(4):501-38. 
Carroll, William K. and Jean Philippe Sapinski. 2016. "Neoliberalism and the Transnational Capitalist Class." Pp. 25-35 in The Handbook of Neoliberalism, Routledge International Handbooks, edited by Simon Springer, Kean Birch, and Julie MacLeavy. New York: Routledge.

Carroll, William K. and Murray Shaw. 2001. "Consolidating a Neoliberal Policy Bloc in Canada, 1976 to 1996." Canadian Public Policy 27(2):195-217.

Chu, Johan S. G. and Gerald F. Davis. 2016. "Who Killed the Inner Circle? The Decline of the American Corporate Interlock Network." American Journal of Sociology 122(3):714-754.

Cronin, Bruce. 2011. "Networks of Corporate Power Revisited.” Procedia - Social and Behavioral Sciences 10:43-51.

David, Thomas and Gerarda Westerhuis, eds. 2014. The Power of Corporate Networks: A Comparative and Historical Perspective. New York and London: Routledge.

Davis, Gerald F. 2008. "A New Finance Capitalism? Mutual Funds and Ownership ReConcentration in the United States." European Management Review 5(1):11-21.

Davis, Gerald F. and Henrich Greve. 1997. "Corporate Elite Networks and Governance Chances in the 1980s." American Journal of Sociology 103(1):1-37.

Davis, Gerald F. and Mark S. Mizruchi. 1999. “The Money Center Cannot Hold: Commercial Banks in the U.S. System of Corporate Governance." Administrative Science Quarterly 44(2):215-39.

Domhoff, G.William. 1967. Who Rules America? Englewood Cliffs (NJ): Prentice-Hall.

Domhoff, G.William. 1974. The Bohemian Grove and Other Retreats: A Study in RulingClass Cohesiveness. 1st ed. New York: Harper \& Row.

Domhoff, G.William. 2014. Who Rules America? The Triumph of the Corporate Rich. 7th ed. New York: McGraw-Hill.

Domhoff, G.William. 2017. “Who Rules America?' Through Seven Editions and 50 Years: Still More Accurate Than Alternative Power Theories." In Studying The Power Elite: Fifty Years Of "Who Rules America?” G. W. Domhoff et al., eds. New York: Routledge.

Fennema, Meindert. 1982. International Networks of Banks and Industry. The Hague: M. Nijhoff. 
Fennema, Meindert and Eelke M. Heemskerk. 2016. "When Theory Meets Methods: The Naissance of the Field of Corporate Interlock Research.”

Fennema, Meindert and Huibert Schijf. 1978. "Analysing Interlocking Directorates: Theory and Methods." Social Networks 1(4):297-332.

Fennema, Meindert and Huibert Schijf. 1985. “The Transnational Network.” Pp. 297-332 in Networks of Corporate Power: A Comparative Analysis of Ten Countries, edited by Frans N Stokman, Rolf Ziegler, and John Scott. Cambridge: Polity Press.

Galaskiewicz, Joseph and Stanley Wasserman. 1981. "A Dynamic Study of Change in a Regional Corporate Network." American Sociological Review 46(4):475-84.

Grbic, Douglas. 2007. “The Source, Structure, and Stability of Control over Japan's Financial Sector." Social Science Research 36(2):469-90.

Harary, Frank. 1969. Graph Theory. Boston: Addison-Wesley.

Heemskerk, Eelke M. 2007. Decline of the Corporate Community: Network Dynamics of the Dutch Business Elite. Amsterdam: Amsterdam University Press.

Heemskerk, Eelke M. 2011. “The Social Field of the European Corporate Elite: A Network Analysis of Interlocking Directorates among Europe's Largest Corporate Boards.” Global Networks 11(4):440-460.

Heemskerk, Eelke M. 2013. "The Rise of the European Corporate Elite: Evidence from the Network of Interlocking Directorates in 2005 and 2010." Economy and Society 42(1):74-101.

Heemskerk, Eelke M. and Meindert Fennema. 2014. "Women on Board: Female Board Membership as a Form of Elite Democratization." Enterprise and Society 15(2):252284.

Heemskerk, Eelke M., Meindert Fennema, and William K. Carroll. 2016. “The Global Corporate Elite after the Financial Crisis: Evidence from the Transnational Network of Interlocking Directorates." Global Networks 16(1):68-88.

Heemskerk, Eelke M. and Frank Takes. 2016. “The Corporate Elite Community Structure of Global Capitalism.” New Political Economy 21(1):90-118.

Heemskerk, Eelke M., Frank W. Takes, Javier Carcia-Bernardo, and M.Jouke Huijzer. 2016. "Where Is the Global Corporate Elite? A Large-Scale Network Study of Local and Nonlocal Interlocking Directorates." Sociologica Forthcoming. 
Helmers, M. H., R. J. Mokken, R. C. Plijter, and F. N. Stokman. 1975. Graven Naar Macht:

Op Zoek Naar de Kern van de Nederlandse Economie [Traces of Power: In Search of the Core of the Dutch Economy]. Amsterdam: Van Gennep.

Hilferding, Rudolf. 1981. Finance Capital: A Study of the Latest Phase of Capitalist Development. London: Routledge \& K. Paul.

Jeidels, Otto. 1905. “Das Verhältnis Der Deutschen Grossbanken Zur Industrie Mit Besonder Berücksichtigung Der Eisenindustrie (Relation of the German Big Banks to Industry with Special Reference to the Iron Industry)." Staats- und sozialwissenschaftliche Forschungen 24(2):1-271.

Kentor, Jeffrey and Yong Suk Jang. 2004. "Yes, There Is a (Growing) Transnational Business Community: A Study of Global Interlocking Directorates 1983-98.” International Sociology 19(3):355-68.

Kick, Edward L., Laura E. McKinney, Steve McDonald, and Andrew K. Jorgenson. 2011. “A Multiple-Network Analysis of the World System of Nations, 1995-1999." Pp. 311-28 in The SAGE handbook of social network analysis, edited by Peter J. Carrington and John Scott. London: SAGE Publications.

Klassen, Jerome and William K. Carroll. 2011. “Transnational Class Formation? Globalization and the Canadian Corporate Network." Journal of World-Systems Research 17(2):379-402.

Koenig, Thomas and Robert Gogel. 1981. "Interlocking Corporate Directorships as a Social Network." American Journal of Economics and Sociology 40(1):37-50.

Kogut, Bruce, ed. 2012. The Small Worlds of Corporate Governance. Boston: MIT Press.

Kogut, Bruce and Gordon Walker. 2001. "The Small World of Germany and the Durability of National Networks." American Sociological Review 66(3):317-35.

Lluch, Andrea, Erica Salvaj, and Maria Ines Barbero. 2014. "Corporate Networks and Business Groups in Argentina in the Early 1970s." Australian Economic History Review 54(2):183-208.

Menshikov, Stanislav M. 1969. Millionaires and Managers: Structure of the U.S. Financial Oligarchy. Moskow: Progress Publishers.

Mills, C.Wright. 1956. The Power Elite. New York: Oxford University Press.

Mintz, Beth and Michael Schwartz. 1985. The Power Structure of American Business. Chicago: University of Chicago Press. 
Mizruchi, Mark S. 1996. "What Do Interlocks Do? An Analysis, Critique, and Assessement of Research on Interlocking Directorates." Annual Review of Sociology 22:271-98.

Mizruchi, Mark S. 2013. The Fracturing of the American Corporate Elite. Cambridge (MA): Harvard University Press.

Murray, Georgina and John Scott, eds. 2012. Financial Elites and Transnational Business: Who Rules the World? Edward Elgar Publishing.

Murray, Joshua. 2014. "Evidence of a Transnational Capitalist Class-for-Itself: The Determinants of PAC Activity among Foreign Firms in the Global Fortune 500, 2000-2006." Global Networks 14(2):230-50.

Murray, Joshua. 2016. "Occupied by Wall Street: Finance Capital at the Center of the Policy Network."

Ornstein, Michael D. 1984. "Interlocking Directorates in Canada: Intercorporate or Class Alliance?” Administrative Science Quarterly 29(2):210-31.

Palmer, Donald. 1987. “The Dual Nature of Corporate Interlocks.” Pp. 60-74 in The Structure of Power in America: The Corporate Elite as a Ruling Class, edited by Michael Schwartz. New York: Holmes \& Meier.

Park, Libby and Frank Park. 1973. Anatomy of Big Business. Toronto: James Lewis \& Samuel.

Peetz, David and Georgina Murray. 2012. “The Financialization of Global Corporate Structures." Pp. 26-53 in Financial Elites And Transnational Business: Who Rules the World?, edited by Georgina Murray and John Scott. Cheltenham (UK) and Northhampton (MA): Edward Elgar Publishing.

Pennings, Johannes M. 1980. Interlocking Directorates: Origins and Consequences of Connections among Organizations'Boards of Directors. San Francisco: Jossey-Bass.

Pfeffer, Jeffrey. 1987. “A Resource Dependence Perspective on Intercorporate Relations.” Pp. 25-55 in Intercorporate Relations: The Structural Analysis of Business, Structural analysis in the social sciences, edited by Mark S. Mizruchi and Michael Schwartz. Cambridge: Cambridge University Press.

van der Pijl, Kees. 1984. The Making of an Atlantic Ruling Class. London: Verso.

van der Pijl, Kees, Otto Holman, and Or Raviv. 2011. “The Resurgence of German Capital in Europe: EU Integration and the Restructuring of Atlantic Networks of Interlocking Directorates after 1991." Review of International Political Economy 18(3):384-408. 
Porter, John. 1956. "Concentration of Economic Power and the Economic Elite in Canada." The Canadian Journal of Economics and Political Science 22(2):199-220.

Ratcliff, Richard E. 1980. "Banks and Corporate Lending: An Analysis of the Impact of the Internal Structure of the Capitalist Class on the Lending Behavior of Banks." American Sociological Review 45(4):553-70.

Richardson, R.Jack. 1987. "Directorship Interlocks and Corporate Profitability.” Administrative Science Quarterly 32(3):367-86.

Salvaj, Erica and Juan Pablo Couyoumdjian. 2016. “Interlocked' Business Groups and the State in Chile (1970-2010).” Business History 58(1):129-48.

Scott, John. 1985. “Theoretical Framework and Research Design.” Pp. 1-19 in Networks of Corporate Power: A Comparative Analysis of Ten Countries, edited by Frans N Stokman, Rolf Ziegler, and John Scott. Cambridge: Polity Press.

Scott, John. 1986. Capitalist Property and Financial Power. Brighton: Wheatsheaf Books. Scott, John. 1991. "Networks of Corporate Power: A Comparative Assessment." Annual Review of Sociology 17:181-203.

Scott, John. 1997. "Big Business and Corporate Power." Pp. 1-20 in Corporate Business and Capitalist Classes. Oxford: Oxford University Press.

Scott, John. 2003. "Transformations in the British Economic Elite." Comparative Sociology 2(1):155-73.

Scott, John. 2008. "Modes of Power and the Re-Conceptualization of Elites." Pp. 27-43 in Remembering Elites. Oxford: Blackwell Publishing.

Scott, John. 2012. "Capital Mobilization, Transnational Structures, and Capitalist Classes." Pp. 1-26 in Financial Elites And Transnational Business: Who Rules the World?, edited by Georgina Murray and John Scott. Northampton (MA): Edward Elgar Publishing.

Slaughter, Sheila, Scott L. Thomas, David R. Johnson, and Sondra N. Barringer. 2014. "Institutional Conflict of Interest: The Role of Interlocking Directorates in the Scientific Relationships between Universities and the Corporate Sector." Journal of Higher Education 85(1):1-35.

Sonquist, John A. and Thomas Koenig. 1975. "Interlocking Directorates in the Top U.S. Corporations: A Graph Theory Approach.” The Insurgent Sociologist 5(3):196-230.

Soref, Michael and Maurice Zeitlin. 1987. "Finance Capital and the Internal Structure of the Capitalist Class in the United States." Pp. 56-84 in Intercorporate Relations: The 
Structural Analysis of Business, Structural analysis in the social sciences, edited by Mark S. Mizruchi and Michael Schwartz. Cambridge: Cambridge University Press.

Stanworth, Philip and Anthony Giddens. 1975. “The Modern Corporate Economy:

Interlocking Directorships in Britain, 1906-1970." The Sociological Review 23(1):528.

Stark, David and Balazs Vedres. 2012. "Political Holes in the Economy: The Business Network of Partisan Firms in Hungary." American Sociological Review 77(5):700 722.

Stokman, Frans N., Jelle Van Der Knoop, and Frans W. Wasseur. 1988. "Interlocks in the Netherlands: Stability and Careers in the Period 1960-1980." Social Networks 10(2):183-208.

Stokman, Frans N., Rolf Ziegler, and John Scott, eds. 1985. Networks of Corporate Power: A Comparative Analysis of Ten Countries. Cambridge: Polity Press.

Useem, Michael. 1984. The Inner Circle: Large Corporations and the Rise of Business Political Activity in the U.S. and U.K. New York: Oxford University Press.

van Apeldoorn, Bastiaan. 2002. Transnational Capitalism and the Struggle Over European Integration. London: Routledge.

Vion, Antoine, François-Xavier Dudouet, and Eric Grémont. 2015. “The Euro Zone Corporate Elite at the Cliff Edge (2005-2008): A New Approach of Transnational Interlocking." Pp. 165-87 in Elites on Trial, vol. 43, Research in the Sociology of Organizations. Emerald Group Publishing.

Vitali, Stefania, James B. Glattfelder, and Stefano Battiston. 2011. “The Network of Global Corporate Control.” PLoS ONE 6(10):e25995.

Whitley, Richard. 1999. Divergent Capitalisms. New York: Oxford University Press.

Windolf, Paul. 2002. Corporate Networks in Europe and the United States. New York: Oxford University Press.

Zweigenhaft, Richard L. and G.William Domhoff. 2013. The New CEOs: Women, African American, Latino, and Asian American Leaders of Fortune 500 Companies. Lanham (MD): Rowman \& Littlefield. 